\title{
Innovation, Creativity, and Entrepreneurship
}

\section{Robert McGowan*}

Professor, Department of Management, Daniels College of Business, USA

While the concept of entrepreneurship has existed for some time, we are witnessing a resurgence in both research as well as formal degree programs. I think this is triggered by a number of factors. One key factor is that most net new growth in jobs today emanates from small to medium-size businesses. Larger firms are turning to alternative organizational forms to compete in the global economy. This ranges from trimming the various managerial layers to strategic outsourcing as well as joint ventures.

A second key factor is that concept of taking an idea to market involves a degree of competitiveness-often lacking in the larger firms. That is not to say it is absent but the vagaries of internal politics and satisfying multiple stakeholders is usually distasteful to the entrepreneur. Indeed, I have known several entrepreneurs who began with larger firms but were adamant that they would do things differently when they began their own business.
A third key factor is that the entrepreneur needs to own the entire process-beginning with idea (which I associate with the innovation process). The creative element involves crafting the business plan, assessing market opportunities, and raising capital. Many times these steps can be quite frustrating but it is the excitement of pulling if off the appeals to the entrepreneur. Indeed, I know of one entrepreneur who stated "how much money I make in the end is not the goal-it is just my way of keeping score."

In sum, entrepreneurship and managing organizations are closely intertwined. One of the challenges going forward is competing in the global arena where products and services are brought together from several countries or regions. This requires focusing on team dynamics, cross-cultural issues and political/legal requirements. The opportunities are boundless yet it needs an individual who is comfortable working in a messy environment.
*Corresponding author: Robert McGowan, Professor, Department of Management, Daniels College of Business, USA, E-mail: rmcgowan@du.edu

Received July 24, 2012; Accepted July 24, 2012; Published July 25, 2012

Citation: McGowan R (2012) Innovation, Creativity, and Entrepreneurship. J Entrepren Organiz Manag 1:e103. doi:10.4172/2169-026X.1000e103

Copyright: () 2012 McGowan R. This is an open-access article distributed under the terms of the Creative Commons Attribution License, which permits unrestricted use, distribution, and reproduction in any medium, provided the original author and source are credited. 